\title{
Iodine, Thyroglobulin and Thyroid Gland
}

\author{
Radovan BÍLEK ${ }^{1}$, Marcela DVOŘÁKOVÁ ${ }^{1}$, Tereza GRIMMICHOVÁ ${ }^{1}$, Jan JISKRA ${ }^{2}$ \\ ${ }^{1}$ Institute of Endocrinology, Prague, Czech Republic, ${ }^{2}$ General Faculty Hospital, Prague, Czech \\ Republic
}

Received March 12, 2020

Accepted March 26, 2020

\begin{abstract}
Summary
Iodine is essential in the biosynthesis of thyroid hormones that affect metabolic processes in the organism from the prenatal state to the elderly. The immediate indicator of iodine intake is the concentration of iodine in urine, but the indicator of iodine intake in the longer term of several months is thyroglobulin $(\mathrm{Tg})$. $\mathrm{Tg}$ negatively correlated with increasing intake of iodine in population that do not suffer from thyroid disease, while a more than adequate to excessive iodine intake leads to an increase in $\mathrm{Tg}$. The dependence of $\mathrm{Tg}$ on iodine can be described by a U-shaped curve. Thyroglobulin in serum is elevated in thyroid disease mainly in hyperthyroidism (diagnosis E05 of WHO ICD-10 codes) and in goiter (diagnosis E04 of WHO ICD-10 codes). $\mathrm{Tg}$ values decrease below $20 \mu \mathrm{g} / \mathrm{l}$ after effective treatment of patients with thyroid disease. Thyroglobulin may thus be an indicator of thyroid stabilization and the success of the thyroid gland treatment.
\end{abstract}

\section{Key words}

Thyroglobulin • Serum • Iodine $\bullet$ Urine $\bullet$ Thyroid gland

\section{Corresponding author}

R. Bílek, Institute of Endocrinology, Národní 8, 11694 Prague 1, Czech Republic. Fax: +42 224905 325. E-mail: rbilek@endo.cz

\section{Introduction}

A healthy endocrine system is a condition for normal development and reproduction. Iodine status is a primary determinant of thyroid disorders in adults, and thyroid disorders belong among major causes of morbidity in Europe, particularly in women. In recent decades the occurrence of thyroid disorder increased and roughly 2 billion people around the world have shown some type of thyroid ailment (WHO 2013). This mainly concerns deficient function of the thyroid (hypothyroidism), which is approximately 6 times more frequent among women than men. Undiagnosed subclinical thyroid disorders further increase this number (McGrogan et al. 2008). Thyroid cancer has the highest increase of occurrence in comparison with other solid tumors. Its occurrence has more than doubled compared to 1973 (Cramer et al. 2010). Thyroid autoimmune disorder is the most frequent organ-specific ailment with a world-wide prevalence of roughly $5 \%$. This is caused by an abnormal interaction taking place between atypical thyrocytes, abnormal antigen-presenting immunity cells and abnormal $\mathrm{T}$ lymphocytes (Klecha et al. 2008). Thyroid problems and other endocrinopathies persist in all industrially developed countries including the Czech Republic and in countries where the environmental pollution is observed (WHO 2013).

Results of our study on thyroid diseases from the period 2012-2015 are based on data of the General Health Insurance Company, Czech Republic (VZP), which has 6 million insured persons (male to female ratio $=1: 1$ ). The set is sufficiently representative to be related to the whole of the Czech Republic. According to VZP data, the prevalence of thyropathies is constantly increasing, for example according to the code of diagnoses E00-E07 (WHO 2016) and the unique birth number, the prevalence of thyropathies increased from $6.8 \%$ in 2012 to $7.5 \%$ in 2015. The increase of the prevalence is mainly concentrated to clinical manifestation of hypothyroidism (code E03, an increase from $2.8 \%$ in 2012 to $3.2 \%$ in 2015); the second is nontoxic goiter (code E04), which 
had a constant prevalence of $2.5 \%$ in the given period. Thyroiditis (code E06), the third in the order of occurrence, increased from $1.8 \%$ in 2012 to $2 \%$ in 2015 (Bilek et al. 2017, Zamrazil et al. 2017).

Insufficient, but also the excessive intake of iodine in the organism itself causes disturbances in thyroid function (Pedersen et al. 2011, Teng et al. 2011, Zimmermann 2009) and apparently also potentiates pathophysiological changes that occur during impaired thyroid function. The determination of urinary iodine is thus important in ensuring the conditions for proper thyroid function, but it cannot directly serve to indicate changes taking place in the thyroid due to its disease.

When a clinically manifest thyroid disorder is detected, treatment that is long-term and controlled by both clinical examination and laboratory diagnostics is essential. Determination of thyroid hormones and factors in the circulation should not only optimize the treatment, but should also point out possible problems that may arise in the patient's condition. The question is which of all hormones and thyroid factors are suitable for this purpose and what changes occur in these parameters. The iodine supply of the thyroid is controlled by determining the urinary iodine concentration. In hypothyroidism, due to thyroid hormone deficiency, thyrotropin (TSH) production is increased, but this should be rapidly suppressed after replacement therapy has been initiated. In hyperthyroidism, there is an excess of thyroid hormones due to increased thyroid activity and TSH production decreases. The use of thyreostatic should correct this situation. Concentration of TSH and free or total thyroid hormones indicates whether substitution or suppression therapy is effective, but changes in thyroid hormone levels in the circulation do not give a clear picture of whether the pathophysiological changes in the thyroid are ongoing, whether they have stopped, and whether the events leading to full restoration of thyroid function were started. Reverse triiodothyronine (rT3) may be important in terms of iodine organization and thyroid hormone biosynthesis balance, it also expresses the level of activity of type I and III deiodinases in both the thyroid and periphery, but its role in impaired thyroid function is not yet clear. In the case of hypothyroidism, reduced rT3 values should be found, while rT3 values increase in severe physical stress and starvation due to activation of deiodinases, thus reducing energy output (Luca et al. 2010). The change in thyroxine-binding globulin (TBG) concentration is important because it depends on the resulting level of total thyroid hormone fractions in the circulation. Since TBG is produced in the liver and its biosynthesis is influenced by mechanisms other than the biological function of thyroid hormones, it cannot be assumed that TBG concentration could reflect the pathophysiological events occurring in the thyroid gland. The autoantibody concentration is directly related to the thyroid pathophysiology and at least one of the autoantibodies, i.e. autoantibodies to thyroglobulin or thyroperoxidase, is present in almost $100 \%$ of cases of autoimmune thyroid involvement (Gentile et al. 2004), and the autoantibodies to TSH receptor assay refines the mechanism of this affection. On the other hand, autoantibodies to thyroglobulin or thyroperoxidase exceed the reference range in approximately $10 \%$ of the healthy population, but there is no evidence of thyroid damage (Hollowell et al. 2002). A better indicator of thyroid status appears to be the dynamics of changes in circulating thyroglobulin ( $\mathrm{Tg}$ ), the only site of biosynthesis being the thyroid, and which is released into the circulation depending on the degree of thyroid damage (Spencer et al. 1996, WHO 2007). Our results show that during successful treatment of thyroid disorders (E01-E890) the Tg level decreases (see below) and thus the decrease of $\mathrm{Tg}$ values is an indicator of improving thyroid condition.

\section{EUthyroid}

Institute of Endocrinology (Czech Republic) participated in the grant of European Commission in the frame of Horizon 2020 Stage 2 - EUthyroid (Towards the elimination of iodine deficiency and preventable thyroidrelated diseases in Europe) proposal number 634453 EUthyroid-RIA, duration 36 months (2015-2018), together with other 22 European Union countries, Island, Canada, Macedonia, Norway, Switzerland and Israel. EUthyroid responds to strategic objective PHC-06-2014: Evaluating existing screening and prevention programs. There are insufficient activities at the EU level to harmonize national legislations, and the Iodine Deficiency Disorders (IDD) prevention and monitoring programs of member states. However, consistent monitoring of iodine supply is essential to match iodine fortification to nutritional habits. In line with the World Health Organization (WHO) recommendations, EUthyroid proposes activities to realize the vision of a euthyroid European population. EUthyroid represents an ambitious project of integrating knowledge and data across 28 countries and a large number of national databases. To overcome fragmented IDD monitoring and 
prevention activities, tailored dissemination activities will target specifically organization in charge of existing IDD prevention programs on the national and regional level, including ministries of health and health-care institutions. EUthyroid generated the first harmonized data set of iodine deficiency resulting in the first valid map of iodine status in Europe. The map demonstrates that iodine deficiency is still present particularly in adults and pregnant women in Europe, according to WHO criteria (WHO 2007). The iodine status of regions is assessed by median urinary iodine concentration determined in representative samples of populations. Interactive European map of iodine status (http://euthyroid.eu/dataanalysismaps/) is an important milestone to encourage stakeholders to improve and harmonize legislations towards Europe and beyond (Ittermann et al. 2020).

\section{Iodine}

About $31 \%$ (1900.9 million) of the world's population is estimated to have insufficient iodine intake, with the most affected World Health Organization regions being South-East Asia and Europe (WHO 2007). Up to 350 million European citizens are exposed to iodine deficiency being at higher risk for developing neurodevelopmental anomalies, since iodine deficiency remains as an important yet preventable cause of brain damage, with tremendous, preventable costs in the health care systems of affected regions. Large parts of Europe can be seen as mildly to moderately iodine deficient with only $27 \%$ of European households having access to iodized salt (Lazarus 2014). An apparent lack of evidence about the iodine status in the European population exists. Little is known about how increasing consumption of convenience food and avoidance of table salt by healthconscious people affects the iodine status. Only very few data are available about the impact on health outcomes and no evidence exists for the cost-effectiveness of current national programs solving problems with the iodine deficiency disorders (IDD). Improving the health outcome of iodine deficiency such as goiter, heart disease and cognitive dysfunction by supplying sufficient iodine to European citizens is a major step in improving public and individual health. It was suggested from the mid1990s that diagnosis and treatment of thyroid disorders due to iodine deficiency in Germany alone amount to 1 billion $€$ annually (Kahaly and Dietlein 2002). Globally Europe is one of the worst regions in terms of access to iodized salt, and a considerable proportion of Europeans live with iodine deficiency due to significant heterogeneity in prevention and monitoring programs. According to the World Health Organization an effective European monitoring program is a crucial step towards eradication of IDD with significant benefits for European citizens and the sustainability of health-care systems (de Benoist et al. 2008).

Several indicators are used to assess the iodine status of a population: thyroid volume, urinary iodine concentration (UIC) and the blood constituent thyrotropin and thyroglobulin (WHO 2004). A major indicator corresponding to iodine nutrition and reflecting recent changes in iodine intake in period of days is concentration of iodine in urine. According to World Health Organization (WHO), United Nations Children's Fund (UNICEF) and International Council for Control of Iodine Deficiency Disorders (ICCIDD), urinary iodine below $20 \mu \mathrm{g} / 1$ denotes severe iodine deficiency, between 20-49 moderate, between 50-99 mild iodine deficiency, UIC between 100-199 is adequate iodine intake, UIC between 200-299 more than adequate, and UIC more than $300 \mu \mathrm{g} / \mathrm{l}$ is excessive iodine intake (WHO 2001, WHO 2007). UIC of pregnant women under $150 \mu \mathrm{g} / 1$ indicate an insufficient iodine intake, between 150-249 is adequate, and between 250-499 is above the required level, over $500 \mu \mathrm{g} / \mathrm{l}$ is excessive iodine intake (WHO 2007). Median urinary iodine concentration $100 \mu \mathrm{g} / \mathrm{l}$ is adequate iodine intake for lactating women and children below 2 years of age (WHO 2007).

The iodine intake by the organism is affected by the amount and quality of the food consumed, primarily by the natural occurrence of iodine in the given area. The Czech Republic has a long past history of iodine deficiency. In some parts of country, endemic cretinism occurred until the beginning of the 20th century. In the period 1947-1953, an extensive epidemiological survey was carried out and approximately 600,000 persons were investigated (Silink et al. 1959). The results showed iodine deficiency in most parts of the Czech Republic. A program of iodine prophylaxis was immediately launched using supplementation of table salt with potassium iodide (5 or $12 \mathrm{ppm}$ ). In 1965 the iodine content was increased to $18 \mathrm{ppm}$, and from 1997 voluntary table salt iodization has been carried out at $20-34 \mathrm{mg} \mathrm{I} / \mathrm{kg}$ table salt using iodine in the form of iodide or iodate. Salt iodization followed by a progressive correction of iodine deficiency. The determination of urinary iodine and in part the determination of $\mathrm{TSH}, \mathrm{Tg}$, 
free thyroxine (FT4), and free triiodothyronine (FT3) was performed in the 5,263 individuals randomly selected from the general population (Bilek et al. 2015, Dvoř́áková et al. 2008, Šterzl et al. 2008) and in the 24,349 individuals who attended the Institute of Endocrinology of Prague in period 1994-2002. The median urinary iodine progressively increased with time starting from values indicating mild iodine deficiency (88-95 $\mu \mathrm{g} / \mathrm{l})$ up to 1997 , reaching the critical threshold $100 \mu \mathrm{g} / \mathrm{l}$ from 1998 to onwards and optimal values between 120 and $140 \mu \mathrm{g} / \mathrm{l}$ since 2000 . The correction of iodine deficiency was not accompanied by unfavourable side effects (Zamrazil et al. 2004). It is evident from our recent results that, according to the WHO, UNICEF and ICCIDD criteria, the Czech Republic has achieved the sustainable elimination of iodine deficiency as a public health problem since the year 2000 (Bilek et al. 2005, Rysava and Kriz 2016, Zamrazil et al. 2004). The iodine prophylaxis has a significant positive effect on ioduria, did not show an increase in abnormal thyroid function, and showed decrease of thyroid volume in women (Zamrazil et al. 2009).

\section{Iodine, pregnant women and their children}

Insufficient iodine intake has a negative effect on the course of thyroid disease and in this situation it is a serious finding that although iodine deficit in the total population has not been a serious health problem since 2000 , iodine supply of pregnant mothers and newborns is not sufficient without special provision. There are also possible consequences of thyroid gland disorders (Hníková et al. 2005).

The role of the iodine in the organism is that it is a substrate for the biosynthesis of thyroid hormones, which influences the metabolism and affects the expression of genes controlling a variety of physiological functions, such as embryogenesis, growth and development of the body, including the neurological and cognitive function. In the nervous system, thyroid hormones are involved in the regulation of cell differentiation and gene expression. T3 binding to nuclear receptors regulates the expression of specific genes in various areas of the brain in both fetal and early postnatal age. In the 1 st and 2 nd trimesters, thyroid hormones have an impact on neuronal proliferation, migration, and organization. At this time the fetus is supplied with thyroid hormones from the mother because the thyroid gland is not yet fully functional. In the third trimester to approximately three years of age occurs in the central nervous system to multiplication, migration and myelination of glial cells. In the 3rd trimester, the fetal thyroid is already capable of producing enough thyroid hormones, only about $30 \%$ of them come from the mother (Dumont et al. 2013, Patel et al. 2011).

The increase in extrathyroidal volume of distribution for thyroid hormones in pregnant women, together with increased renal excretion of iodine due to $50 \%$ increased glomerular filtration accompanied by decreased tubular resorption results in increased demand for iodine uptake into the body. Deiodinase III activity, that degrades T4 and T3 to inactive metabolites, increases in the placenta in the third trimester, and thus protects the fetus from an excess of thyroid hormones after initiation of biosynthesis of these hormones in fetal thyroid and again increases the production of thyroid hormones in the thyroid gland (Dumont et al. 2013). Thus, the body of pregnant women needs about $50 \%$ increase in iodine intake to maintain physiological production of thyroid hormones in both the mother and the fetus (Zimmermann 2016). Pregnant women should receive dietary supplements containing iodine if they live in an area where the median iodine is generally less than $100 \mu \mathrm{g} / \mathrm{l}$ (Andersen and Laurberg 2016). In women living in areas with sufficient iodine supply, thyroid volume increases by $10 \%$ during pregnancy, women living in areas with iodine deficiency have thyroid volume increased by 20-40 \% (Stagnaro-Green et al. 2011).

It is known that insufficient intake of iodine by the human organism results in a series of functional as well as developmental abnormalities, which can, in extreme cases, lead to the endemic goiter and cretinism, to the endemic mental retardation, increased prenatal and neonatal mortality and decreased fertility. The main societal concern with iodine deficiency is the negative impact on neurocognition in unborn and children. There is empirical evidence that the mean national IQ and the gap between rich and poor countries correlate, which according to the authors is a causal relationship (Lynn and Vanhanen 2002). Therefore, it is of important societal concern to provide enough iodine supply to the next generation and, moreover, if inequalities of iodine supply exist, to ensure the chances of societal advance for those at economic disadvantage. Iodine deficiency disorders represent a global health threat to individuals and societies. The adverse effects of iodine deficiency are diverse and impose a significant burden on public healthcare systems. Adults living in iodine-deficient regions carry a high risk of goiter, thyroid nodules and 
hyperthyroidism. Subclinical hyperthyroidism, as a common and frequently undiagnosed IDD, is tightly associated with an increased risk of mortality and coronary heart disease. Moreover, iodine deficiency during pregnancy and breast-feeding is widespread in Europe and adversely affects the development of the child. Even mild or moderate iodine deficiency of the mother affects the synthesis of thyroid hormones and may impair brain development, neurocognitive function and reduces offspring IQ. During pregnancy, women have a sharply increased need for iodine, which is frequently not covered by food sources and iodine supplements. Due to a lack of valid data, we are uncertain about the scale of the problem, but estimates suggest that up to $50 \%$ of newborns in Europe are at risk of iodine deficiency (EUthyroid Consortium 2018).

Insufficient intake of iodine in the food endangers in particular pregnant women and their fetuses, newborns and suckling babies. The physical development of the child is retarded, and its mental functions are not fully developed (Delange 2002, Hetzel 2002). Pregnant women represent a specific subgroup of the general population. During pregnancy, iodine demand is higher, which is taken into account in the WHO cut-off for sufficient iodine supply $150 \mu \mathrm{g} / \mathrm{l}$ (WHO 2007). Pregnant women are recommended to take iodine supplementation in some countries (Ittermann et al. 2018), which hampers the comparison between iodine status in pregnant women and other populations in a study region. Furthermore, pregnant women drink more water leading to a higher dilution of the urine samples and in consequence to lower UIC (Bath and Rayman 2015). For these reasons, monitoring studies in pregnant women should not be used to characterize the iodine status of the general population and should be assessed separately from monitoring studies in children and adults.

In EUthyroid research concerning pregnant women, 11 studies were enrolled, in 7 studies $(63.6 \%)$ the median ioduria was less than $150 \mu \mathrm{g} / \mathrm{l}$. Our older studies have shown that the results of iodine nutrition of pregnant women are alarming. On average, only $30 \%$ of the total of 750 examined women in the period 2010-2015 have urinary iodine values greater than $150 \mu \mathrm{g} / 1$ and therefore meet the requirements of the WHO for pregnant women (Bilek et al. 2016). In period 2008-2011, only $17 \%$ of 181 women $2-8$ weeks after an early spontaneous abortion have urinary iodine values greater than $150 \mu \mathrm{g} / \mathrm{l}$ (Jiskra et al. 2014). Similarly, maternal UIC $>150 \mu \mathrm{g} / \mathrm{l}$ at time of delivery was found in only 2 of 17 women without iodine supplementation (Krylova et al. 2017). These data demonstrate that particularly pregnant women are affected by iodine deficiency in Europe, emphasizing the importance of monitoring studies and an improved iodine status in this vulnerable subgroup (Ittermann et al. 2020). Thyroglobulin may be a promising functional biomarker of both iodine deficiency and excess (Bilek and Cerovska 2006, Bilek et al. 2015, Bílek and Zamrazil 2009, Zimmermann et al. 2013) and can also be used in pregnant women (Eltom et al. 2000, Ma and Skeaff 2014, Nohr and Laurberg 2000).

\section{Thyroglobulin}

Thyroglobulin originates only in the thyroid gland where the synthesis of thyroid hormones takes place. It is the major iodoglycoprotein of the thyroid gland (molecular weight of soluble dimer about $660 \mathrm{kDa}$, $0.1-2.0 \%$ iodine; $8-10 \%$ total carbohydrate with galactose, mannose, fucose, $\mathrm{N}$-acetyl glucosamine and sialic acid residues) (Venkatesh and Deshpande 1999), which consists of two identical subunits (homodimer), and belongs to the type B carboxylesterase/lipase family (Park and Arvan 2004). The serum Tg concentrations primarily reflect three factors: a) the mass of differentiated thyroid tissue present; b) any physical damage to or inflammation of the thyroid gland; and c) the magnitude of thyrotropin receptor stimulation (Spencer et al. 1996). The thyroid hyperplasia and goiter characteristic of iodine deficiency increases serum $\mathrm{Tg}$ levels, and, in this setting, the concentration of serum $\mathrm{Tg}$ reflects iodine nutrition over a period of months or years (WHO 2007).

In iodine-deficient areas the serum $\mathrm{Tg}$ concentration is elevated due to TSH hyperstimulation or thyroid hyperplasia (Zimmermann et al. 2006). Serum thyroglobulin and urinary iodine concentration are the most appropriate indicators of iodine status and thyroid function under conditions of increasing iodine supply (Van Den Briel et al. 2001), because thyroid volume, thyroid nodularity or iodine excretion had close associations to serum $\mathrm{Tg}$ (Knudsen et al. 2001). Significant inverse correlations were found for relationships between measures of urinary iodide excretion and serum thyroglobulin (Raverot et al. 2012, Simsek et al. 2003, Skeaff et al. 2012, Thomson et al. 2001).

In a cross-sectional study in primary schools in 
12 countries with children 6 to 12 years of age $(n=2,512)$ it was found that, over a range of iodine intakes from severely deficient to excessive, $\mathrm{Tg}$ concentrations showed a clear U-shaped curve and median values of $\mathrm{Tg}$ in dried whole blood spots between 13 and $40 \mu \mathrm{g} / \mathrm{l}$ indicate iodine sufficiency in the population of 5 to 14 year-old children (Zimmermann et al. 2013, Zimmermann et al. 2006).

EUthyroid will also evaluate the potential of thyroglobulin as marker for the individual iodine status, which is the main innovation within EUthyroid. In the project EUthyroid, serum thyroglobulin and its autoantibodies were measured in 3,712 sera of pregnant women at ETHZ (Switzerland). In this study, association between maternal thyroglobulin in pregnancy and UIC was found (Stinca et al. 2017).

Our work concerning $\mathrm{Tg}$ as a biomarker of iodine nutrition based on our population studies have been published (Bilek et al. 2015). The relationship is shown between a concentration of urinary iodine and serum thyroglobulin in population studies carried out on a general population that was randomly selected from the registry of the General Health Insurance Company (individuals aged 6-98 years, 1,751 males, 2,420 females). The individuals were divided into subgroups with a urinary iodine concentration of $<50,50-99,100-199$, 200-299 and $\geq 300 \mu \mathrm{g} / \mathrm{l}$. The mean and median of thyroglobulin were calculated in these subgroups. Upper nonparametric tolerance limits of thyroglobulin in relation to iodine intake were calculated in subgroup of normal individuals $(\mathrm{n}=1858$, thyroglobulin, urinary iodine, thyrotropin and free thyroxine were within the normal reference range). Upper limits were dependent on gender and age. The total value of upper limits is $44 \mu \mathrm{g} / \mathrm{l}$; for individuals aged $6-17$ years it is $39.1 \mu \mathrm{g} / \mathrm{l} ; 18-65$ years $=51.4 \mu \mathrm{g} / \mathrm{l}$ and $66-98$ years $=60.6 \mu \mathrm{g} / \mathrm{l}$. In general, thyroglobulin serum concentrations higher than $40 \mu \mathrm{g} / \mathrm{l}$ should be an indicator for determining urinary iodine. The significance of determining the $\mathrm{Tg}$ is broader than its common use as an indicator of the state of the patient with differentiated carcinoma of the thyroid (Bílek and Dvořáková 2018).

\section{Problems of immunoanalytical determination of $\mathrm{Tg}$}

Serum $\mathrm{Tg}$ is currently measured by immunoassay, and Tg belongs among the difficult serum assays in current routine diagnostic due to the lack of homogeneity of the large $\mathrm{Tg}$ molecule, where various isoforms of Tg exist with differences both in the primary structure and iodine or carbohydrate content. These factors determine the three-dimensional conformation of the molecule, and thus they can reduce the epitopes important for immunoanalytical interactions. The standardization of antibodies used to determine circulating $\mathrm{Tg}$ can be a most important step for obtaining the comparable results across many commercially available Tg assays (Bílek and Zamrazil 2009). Iodine intake was not taken into account when determining normal $\mathrm{Tg}$ values (Zimmermann et al. 2006). In addition, Tg immunoassay may be limited by the presence of autoantibodies to $\mathrm{Tg}$ and heterophilic antibodies, which generally impair the accuracy, i.e. precision and truth, of immunoanalytically determined $\mathrm{Tg}$. In particular, immunometric (sandwich) analyzes, which are characterized by false low results (Giovanella and Ceriani 2011), are affected. Competitive immunoassay is more resistant to Tg autoantibodies (Spencer et al. 2005), but here too, there may be a decrease in the availability of labeled Tg as an indicator of the degree of competition within the immunoanalytical process, leading to false high results. The problem of heterophilic antibodies is compromised by the use of agents blocking these antibodies (Giovanella et al. 2009). Excessive iodine intake (Teng et al. 2011) or the introduction of an iodine prophylaxis program (Pedersen et al. 2011) usually results in an increase in the prevalence of autoantibodies to $\mathrm{Tg}$.

Result of international cooperation under the auspices of the Community Bureau of Reference of the Commission of the European Communities provides the production and distribution of Tg standard CRM-457 (Feldt-Rasmussen et al. 1996a, Feldt-Rasmussen et al. 1996b), the use of which reduce the interassay coefficient of variation from $47 \%$ to $37 \%$ when compared to Tg kits from different manufacturers (Spencer et al. 2005). However, this value is not satisfactory and indicates the persistence of substantial differences in the determination of $\mathrm{Tg}$. A promise for the future is the possibility to determine Tg by mass spectrometry (Hoofnagle and Roth 2013, Kushnir et al. 2013), where autoantibodies or heterophilic antibodies do not affect the accuracy of the assay.

\section{Our preliminary results}

Methods used for determination of iodine and thyroglobulin in Institute of Endocrinology

The laboratory procedure for spectrophotometric determination of iodine will be used to determine iodine 
in biological material. It consists of mineralization by alkaline ashing with subsequent Sandell-Kolthoff's reaction (Bilek et al. 2005). The detection limit of the method is $2.6 \mu \mathrm{g} \mathrm{I} / 1$, the limit of quantification $11.7 \mu \mathrm{g} \mathrm{I} / 1$, intra-assay precision $4 \%$, and inter-assay precision $4.9 \%$. This method has been accredited by the Czech Accreditation Institute (ČSN ISO 15189:2013) in the year 2015. Within Euthyroid, the verification study on 75 urine samples between Institute of Endocrinology, Prague (Sandell-Kolthoff reaction subsequent to dry alkaline ashing) and an accredited laboratory in CRL Helsinki (Inductively Coupled Plasma Mass Spectrometry) was performed with result that Pearson's correlation coefficient had a value equal to 0.957 .

CDC (Centers for Disease Control and Prevention, Atlanta, USA) established its Ensuring the Quality of Urinary Iodine Procedures (EQUIP) program in 2001 to provide laboratories that measure UIC with an independent assessment of their analytical performance. The program, which is voluntary and free-of-charge, currently works with more than 120 iodine laboratories in the USA and over 60 countries. The Institute of Endocrinology in Prague joined this program in 2017 and has $100 \%$ successes to date.

Serum Tg was determined from 2000 to 2019 with the 1-step electrochemiluminometric sandwich assay (ECLIA, code 1820834 Elecsys Tg Immunoassay, Roche Diagnostics, Mannheim, Germany) using monoclonal mouse antibodies and streptavidin technology. The standards have been calibrated against BCR standard CRM 457 (reference range 0-85 $\mu \mathrm{g} / \mathrm{l}$ ).
Human subjects examined at the Institute of Endocrinology

In the period 2000-2019, in which $\mathrm{Tg}$ was determined as described in the previous section, patient data related to $\mathrm{Tg}$ measurements were analyzed after division by ICD-10 codes (WHO 2016) in the diagnosis of E01 (iodine-deficiency-related thyroid disorders and allied conditions), E02 (subclinical iodine-deficiency hypothyroidism), E03 (other hypothyroidism), E04 (other non-toxic goitre), E05 (thyrotoxicosis [hyperthyroidism]), E06 (thyroiditis), E07 (other disorders of thyroid), E890 (postsurgical hypothyroidism). Figure 1 shows $\mathrm{Tg}$ concentrations at the first patient visit in the Institute of Endocrinology $(\mathrm{n}=21,866,3,414$ males, 18,452 females, mean age \pm standard deviation $49 \pm 18$ years). It can be seen from the figure that the highest average $\mathrm{Tg}$ values were recorded in the diagnosis of E05, followed by the diagnoses E04, E01, E03, E07, E06, E02, the lowest $\mathrm{Tg}$ concentration corresponded to the diagnosis E890.

The mean thyroglobulin concentration in repeated patient determinations at approximately halfyear intervals with diagnoses E01, E02, E03, E04, E05, E06, E07, E890 in the period 2000-2019 (65,084 Tg analyzes) is shown in Figure 2. It can be seen from the figure that thyroglobulin decreased with stabilization of the thyroid gland. The exception is the peak at 8-9 years of follow-up, in which the dose of thyrostatic (methymazole, propylthiouracil) was increased in patients diagnosed with E05 due to their worsened condition.

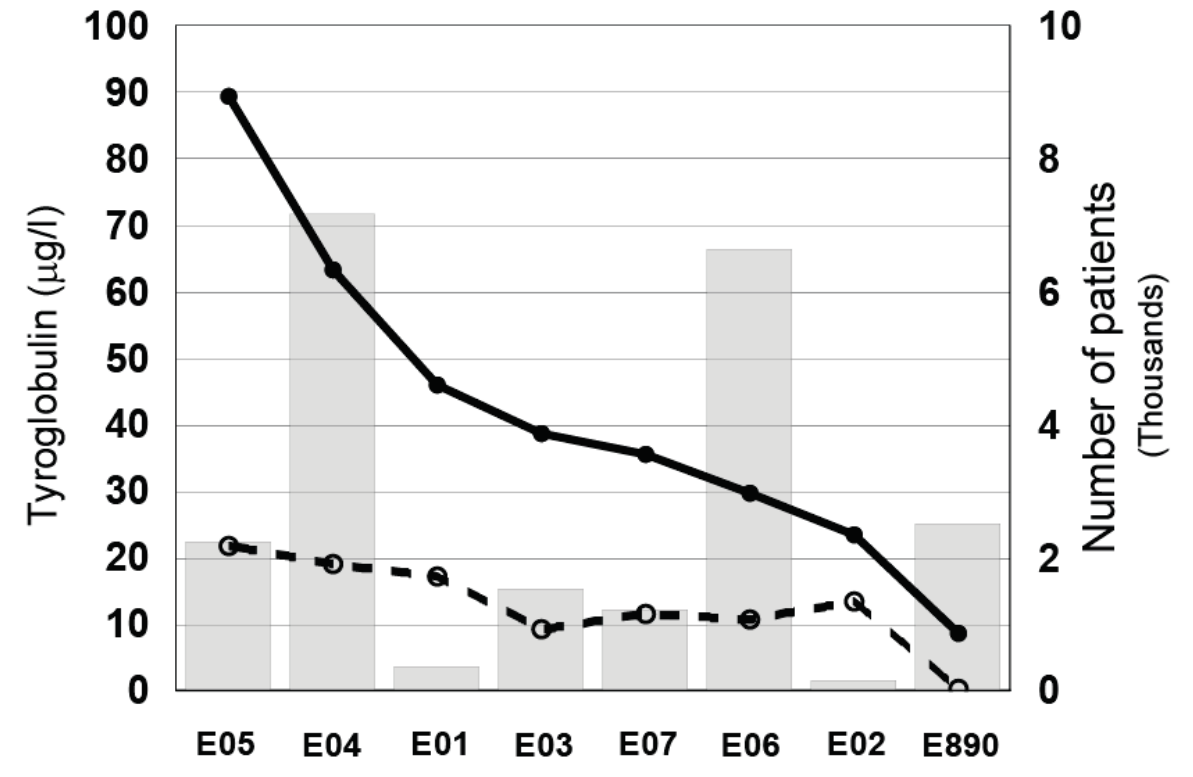

Fig. 1. Mean $(-\boldsymbol{C})$, median (- $-\mathbf{O})$ of thyroglobulin in a given number of patients ( $($ ) at first visit to the Institute of Endocrinology diagnosed with E01 (iodine-deficiency-related thyroid disorders and allied conditions), E02 (subclinical iodine-deficiency hypothyroidism), E03 (other hypothyroidism), E04 (other non-toxic goitre), E05 (thyrotoxicosis [hyperthyroidism]), E06 (thyroiditis), E07 (other disorders of thyroid), E890 (postsurgical hypothyroidism). 


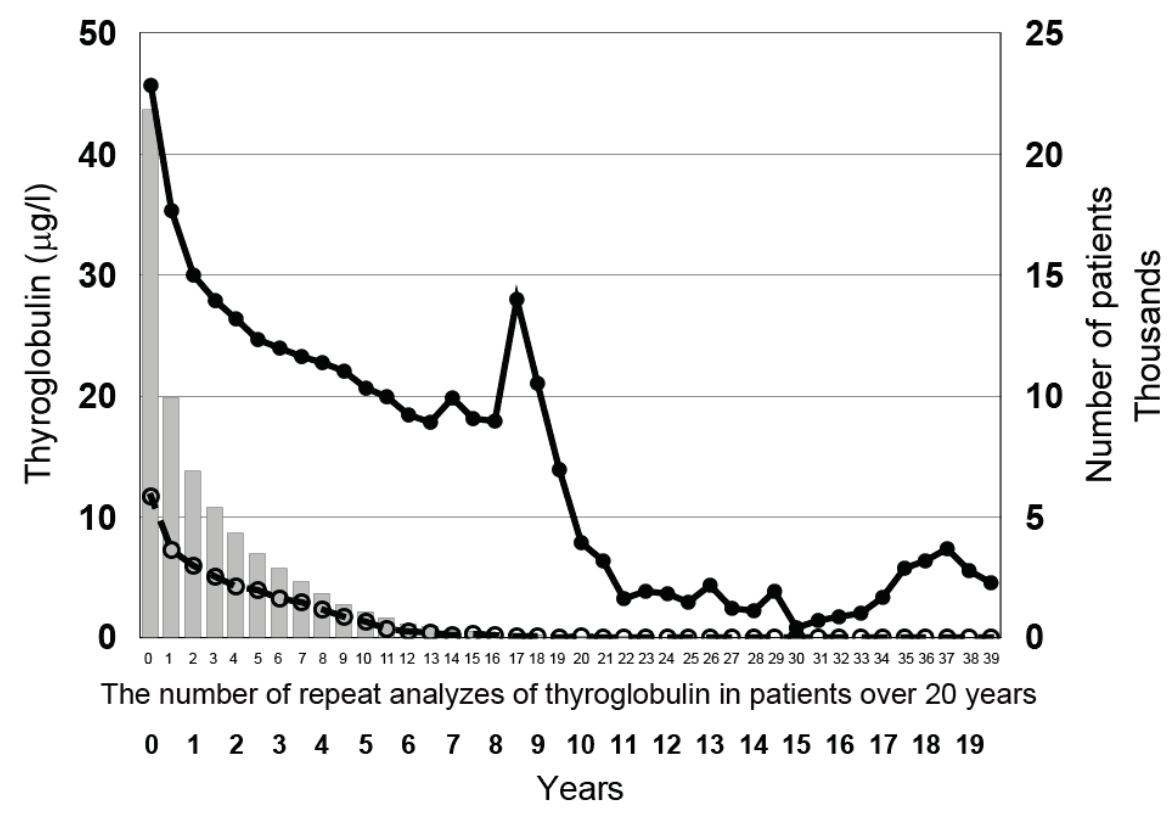

Fig. 2. Concentration of thyroglobulin (mean -, median $=0-$, number of patients ) in repeated assays of patients diagnosed with E01, E02, E03, E04, E05, E06, E07, E890 over the 20 years of follow-up. Patients were checked at approximately half-year intervals.

Population studies on the relationship between thyroglobulin and iodine in urine depending on gender and age are described in literature (Bilek et al. 2015). The relationship between $\mathrm{Tg}$ and UIC corresponds to the U-shaped curve. Exceptions were people over 65 years of age, in whom the rising UIC also increased $\mathrm{Tg}$ to values higher than $100 \mu \mathrm{g} / \mathrm{l}$. Therefore, iodine supplementation in seniors should be carefully controlled. In children and seniors, higher $\mathrm{Tg}$ concentrations were observed with severe iodine deficiency compared to the normal healthy adult population.

\section{Conflict of Interest}

There is no conflict of interest.

\section{Acknowledgement}

Supported by MH CZ - DRO (Institute of Endocrinology - EÚ, 00023761).

\section{References}

ANDERSEN SL, LAURBERG P: Iodine supplementation in pregnancy and the dilemma of ambiguous recommendations. Eur Thyroid J 5: 35-43, 2016. https://doi.org/10.1159/0004444254

BATH SC, RAYMAN MP: A review of the iodine status of UK pregnant women and its implications for the offspring. Environ Geochem Health 37: 619-629, 2015. https://doi.org/10.1007/s10653-015-9682-3

BILEK R, CEROVSKA J: Iodine and thyroid hormones (in Czech). Vnitr Lek 52: 881-886, 2006.

BÍLEK R, ZAMRAZIL V: Thyroglobulin as an indicator of iodine intake. In: Comprehensive Handbook on Iodine: Nutritional, Biochemical, Pathological and Therapeutic Aspects. VR PREEDY, GN BURROW, R WATSON (eds), Academic Press, Oxford, 2009, pp 55-64. https://doi.org/10.1016/B978-0-12-374135-6.00006-6

BÍLEK R, DVOŘÁKOVÁ M: Thyroglobulin and other laboratory diagnosis parameters in treating hypothyroidism in children. (In Czech) Ces-slov Pediat 73: 72-78, 2018.

BILEK R, BEDNAR J, ZAMRAZIL V: Spectrophotometric determination of urinary iodine by the Sandell-Kolthoff reaction subsequent to dry alkaline ashing. Results from the Czech Republic in the period 1994-2002. Clin Chem Lab Med 43: 573-580, 2005. https://doi.org/10.1515/CCLM.2005.100

BILEK R, CEROVSKA J, ZAMRAZIL V: The relationship between iodine intake and serum thyroglobulin in the general population. Physiol Res 64: 345-353, 2015. https://doi.org/10.33549/physiolres.932840

BILEK R, KANOVA N, MINDZAKOVA V, NEUMANN D, JISKRA J, RYSAVA L, ZAMRAZIL V: Iodine supply of pregnant women in the Czech Republic. (In Czech) Vnitr Lek 62 (Suppl 3): 10-16, 2016. 
BILEK R, HORAKOVA L, GOS R, ZAMRAZIL V: Thyroid disease in the Czech Republic: the EUthyroid project and the evaluation of the General Health Insurance Company epidemiological data for the period of 2012-2015. (In Czech) Vnitr Lek 63: 548-554, 2017.

CRAMER JD, FU P, HARTH KC, MARGEVICIUS S, WILHELM SM: Analysis of the rising incidence of thyroid cancer using the Surveillance, Epidemiology and End Results national cancer data registry. Surgery 148: 1147-1152; discussion 1152-1143, 2010. https://doi.org/10.1016/j.surg.2010.10.016

DE BENOIST B, MCLEAN E, ANDERSSON M, ROGERS L: Iodine deficiency in 2007: global progress since 2003. Food Nutr Bull 29: 195-202, 2008. https://doi.org/10.1177/156482650802900305

DELANGE F: Iodine deficiency in Europe and its consequences: an update. Eur J Nucl Med Mol Imaging 29 (Suppl 2): S404-S416, 2002. https://doi.org/10.1007/s00259-002-0812-7

DUMONT JE, MAENHAUT C, CHRISTOPHE D, VASSART G, ROGER PP: Thyroid regulatory factors. In: Endocrinology Adult and Pediatric (6th Edition). LD GROOT, J JAMESON (eds), Saunders, Elsevier Inc., Milton Keynes, 2013, pp 1384-1408.

DVOŘÁKOVÁ M, HILL M, ČEŘOVSKÁ J, POBIŠOVÁ Z, BÍLEK R, HOSKOVCOVÁ P, ZAMRAZIL V, HAINER V: Relationship between pituitary-thyroid axis hormones and anthropometric parameters in Czech adult population. Physiol Res 57 (Suppl 1): S127-S134, 2008.

ELTOM A, ELNAGAR B, ELBAGIR M, GEBRE-MEDHIN M: Thyroglobulin in serum as an indicator of iodine status during pregnancy. Scand J Clin Lab Invest 60: 1-7, 2000. https://doi.org/10.1080/00365510050184985

EUTHYROID CONSORTIUM: The Krakow Declaration on Iodine: tasks and responsibilities for prevention programs targeting iodine deficiency disorders. Eur Thyroid J 7: 201-204, 2018. https://doi.org/10.1159/000490143

FELDT-RASMUSSEN U, PROFILIS C, COLINET E, BLACK E, BORNET H, BOURDOUX P, CARAYON P, ERICSSON UB, KOUTRAS DA, LAMAS DE LEON L, DENAYER P, PACINI F, PALUMBO G, SANTOS A, SCHLUMBERGER M, SEIDEL C, VAN HERLE AJ, De VIJLDER JJ: Human thyroglobulin reference material (CRM 457). 1st Part: Assessment of homogeneity, stability and immunoreactivity. Ann Biol Clin (Paris) 54: 337-342, 1996a.

FELDT-RASMUSSEN U, PROFILIS C, COLINET E, BLACK E, BORNET H, BOURDOUX P, CARAYON P, ERICSSON UB, KOUTRAS DA, LAMAS DE LEON L, DENAYER P, PACINI F, PALUMBO G, SANTOS A, SCHLUMBERGER M, SEIDEL C, VAN HERLE AJ, DE VIJLDER JJ: Human thyroglobulin reference material (CRM 457). 2nd Part: Physicochemical characterization and certification. Ann Biol Clin (Paris) 54: 343-348, 1996b.

GENTILE F, CONTE M, FORMISANO S: Thyroglobulin as an autoantigen: what can we learn about immunopathogenicity from the correlation of antigenic properties with protein structure? Immunology 112: 13-25, 2004. https://doi.org/10.1111/j.1365-2567.2004.01861.x

GIOVANELLA L, CERIANI L: Comparison of thyroglobulin antibody interference in first- and second-generation thyroglobulin immunoassays. Clin Chem Lab Med 49: 1025-1027, 2011. https://doi.org/10.1515/CCLM.2011.155

GIOVANELLA L, KELLER F, CERIANI L, TOZZOLI R: Heterophile antibodies may falsely increase or decrease thyroglobulin measurement in patients with differentiated thyroid carcinoma. Clin Chem Lab Med 47: 952-954, 2009. https://doi.org/10.1515/CCLM.2009.230

HETZEL BS: Eliminating iodine deficiency disorders-the role of the International Council in the global partnership. Bull World Health Organ 80: 410-413, 2002.

HNÍKOVÁ O, DELANGE F, KRAČMAR P, VINOHRADSKÁ H, BÍLEK R: Experience in the monitoring of maternal and neonatal iodine supply in the Czech Republic. (In Czech) Ces-slov Pediat 60: 3-6, 2005.

HOLLOWELL JG, STAEHLING NW, FLANDERS WD, HANNON WH, GUNTER EW, SPENCER CA, BRAVERMAN LE: Serum TSH, T(4), and thyroid antibodies in the United States population (1988 to 1994): National Health and Nutrition Examination Survey (NHANES III). J Clin Endocrinol Metab 87: 489-499, 2002. https://doi.org/10.1210/jcem.87.2.8182

HOOFNAGLE AN, ROTH MY: Clinical review: improving the measurement of serum thyroglobulin with mass spectrometry. J Clin Endocrinol Metab 98: 1343-1352, 2013. https://doi.org/10.1210/jc.2012-4172 
ITTERMANN T, VOLZKE H, KREY A, REMER T, HECKMANN M, LANGE A, KRAMER A, BELOW H: Median urinary iodine concentration reflected sufficient iodine supply in neonates from Northeast Germany in 2005-2006. Eur J Nutr 58: 1815-1820, 2018. https://doi.org/10.1007/s00394-018-1731-0

ITTERMANN T, ALBRECHT D, AROHONKA P, BILEK R, DE CASTRO JJ, DAHL L, NYSTROM HF, GABERSCEK S, GARCIA-FUENTES E, GHEORGHIU ML, HUBALEWSKA-DYDEJCZYK A, HUNZIKER S, JUKIC T, KARANFILSKI B, KUSIC Z, MAJSTOROV V, MAKRIS KC, MARKOU KB, MEISINGER C, KOSTOVA NM, NAGY EV, PIRAGS V, ROJO-MARTINEZ G, SAMARDZIC M, SARANAC L, SCHAUER B, STRELE I, THAMM M, TOP I, TROFIMIUK-MULDNER M, ÜNAL B, VILA L, VITTI P, WINTER B, WOODSIDE JV, ZALETEL K, ZAMRAZIL V, ZIMMERMANN M, ERLUND I, VÖLZKE H: Standardized map of iodine status in Europe. Thyroid 30: 1346-1354, 2020. https://doi.org/10.1089/thy.2019.0353

JISKRA J, FAIT T, BILEK R, KRATKY J, BARTAKOVA J, LUKAS J, LIMANOVA Z, TELICKA Z, ZAMRAZIL $\mathrm{V}$, POTLUKOVA E: Mild iodine deficiency in women after spontaneous abortions living in an iodine-sufficient area of Czech Republic: prevalence and impact on reproductive health. Clin Endocrinol (Oxf) 80: 452-458, 2014. https://doi.org/10.1111/cen.12298

KAHALY GJ, DIETLEIN M: Cost estimation of thyroid disorders in Germany. Thyroid 12: 909-914, 2002. https://doi.org/10.1089/105072502761016548

KLECHA AJ, BARREIRO ARCOS ML, FRICK L, GENARO AM, CREMASCHI G: Immune-endocrine interactions in autoimmune thyroid diseases. Neuroimmunomodulation 15: 68-75, 2008. https://doi.org/10.1159/000135626

KNUDSEN N, BULOW I, JORGENSEN T, PERRILD H, OVESEN L, LAURBERG P: Serum Tg-a sensitive marker of thyroid abnormalities and iodine deficiency in epidemiological studies. J Clin Endocrinol Metab 86: 3599-3603, 2001. https://doi.org/10.1210/jcem.86.8.7772

KRYLOVA K, BILEK R, KULICKA J, DEJMEK P, BAYER M, KACEROVSKY M, NEUMANN D: Urinary iodine concentrations in mothers and their term newborns in country with sufficient iodine supply. J Matern Fetal Neonatal Med 30: 2633-2639, 2017. https://doi.org/10.1080/14767058.2016.1260114

KUSHNIR MM, ROCKWOOD AL, ROBERTS WL, ABRAHAM D, HOOFNAGLE AN, MEIKLE AW: Measurement of thyroglobulin by liquid chromatography-tandem mass spectrometry in serum and plasma in the presence of antithyroglobulin autoantibodies. Clin Chem 59: 982-990, 2013. https://doi.org/10.1373/clinchem.2012.195594

LAZARUS JH: Iodine status in Europe in 2014. Eur Thyroid J 3: 3-6, 2014. https://doi.org/10.1159/000358873

LUCA F, GOICHOT B, BRUE T: Non thyroidal illnesses (NTIS). Ann Endocrinol (Paris) 71 (Suppl 1): S13-S24, 2010. https://doi.org/10.1016/S0003-4266(10)70003-2

LYNN R, VANHANEN T: IQ and the wealth of nations. Praeger Publishers, Westport, CT, 2002.

MA ZF, SKEAFF SA: Thyroglobulin as a biomarker of iodine deficiency: a review. Thyroid 24: 1195-1209, 2014. https://doi.org/10.1089/thy.2014.0052

MCGROGAN A, SEAMAN HE, WRIGHT JW, DE VRIES CS: The incidence of autoimmune thyroid disease: a systematic review of the literature. Clin Endocrinol (Oxf) 69: 687-696, 2008. https://doi.org/10.1111/j.13652265.2008.03338.X

NOHR SB, LAURBERG P: Opposite variations in maternal and neonatal thyroid function induced by iodine supplementation during pregnancy. J Clin Endocrinol Metab 85: 623-627, 2000. https://doi.org/10.1210/jc.85.2.623

PARK YN, ARVAN P: The acetylcholinesterase homology region is essential for normal conformational maturation and secretion of thyroglobulin. J Biol Chem 279: 17085-17089, 2004. https://doi.org/10.1074/jbc.M314042200

PATEL J, LANDERS K, LI H, MORTIMER RH, RICHARD K: Thyroid hormones and fetal neurological development. J Endocrinol 209: 1-8, 2011. https://doi.org/10.1530/JOE-10-0444

PEDERSEN IB, KNUDSEN N, CARLE A, VEJBJERG P, JORGENSEN T, PERRILD H, OVESEN L, RASMUSSEN LB, LAURBERG P: A cautious iodization programme bringing iodine intake to a low recommended level is associated with an increase in the prevalence of thyroid autoantibodies in the population. Clin Endocrinol (Oxf) 75: 120-126, 2011. https://doi.org/10.1111/j.1365-2265.2011.04008.x 
RAVEROT V, BOURNAUD C, SASSOLAS G, ORGIAZZI J, CLAUSTRAT F, GAUCHERAND P, MELLIER G, CLAUSTRAT B, BORSON-CHAZOT F, ZIMMERMANN M: Pregnant French women living in the Lyon area are iodine deficient and have elevated serum thyroglobulin concentrations. Thyroid 22: 522-528, 2012. https://doi.org/10.1089/thy.2011.0184

RYSAVA L, KRIZ J: Solution of Iodine deficiency in the Czech Republic - history and current situation. 20 years of work of prof. Vaclav Zamrazil for Commission for the solution of iodine deficiency. (In Czech) Vnitr Lek 62: 103-106, 2016.

SILINK K, REINSENAUER R, CHALOUPSKY J: The problem of mapping endemic goiter in Czechoslovakia. Rev Czech Med 5: 73-88, 1959.

SIMSEK E, SAFAK A, YAVUZ O, ARAS S, DOGAN S, KOCABAY K: Sensitivity of iodine deficiency indicators and iodine status in Turkey. J Pediatr Endocrinol Metab 16: 197-202, 2003. https://doi.org/10.1515/JPEM.2003.16.2.197

SKEAFF SA, THOMSON CD, WILSON N, PARNELL WR: A comprehensive assessment of urinary iodine concentration and thyroid hormones in New Zealand schoolchildren: a cross-sectional study. Nutr J 11: 31, 2012. https://doi.org/10.1186/1475-2891-11-31

SPENCER CA, TAKEUCHI M, KAZAROSYAN M: Current status and performance goals for serum thyroglobulin assays. Clin Chem 42: 164-173, 1996. https://doi.org/10.1093/clinchem/42.1.164

SPENCER CA, BERGOGLIO LM, KAZAROSYAN M, FATEMI S, LOPRESTI JS: Clinical impact of thyroglobulin ( $\mathrm{Tg}$ ) and $\mathrm{Tg}$ autoantibody method differences on the management of patients with differentiated thyroid carcinomas. J Clin Endocrinol Metab 90: 5566-5575, 2005. https://doi.org/10.1210/jc.2005-0671

STAGNARO-GREEN A, ABALOVICH M, ALEXANDER E, AZIZI F, MESTMAN J, NEGRO R, NIXON A, PEARCE EN, SOLDIN OP, SULLIVAN S, WIERSINGA W: Guidelines of the American Thyroid Association for the diagnosis and management of thyroid disease during pregnancy and postpartum. Thyroid 21: 1081-1125, 2011. https://doi.org/10.1089/thy.2011.0087

ŠTERZL I, HRDÁ P, MATUCHA P, ČEǨOVSKÁ J, ZAMRAZIL V: Anti-helicobacter pylori, anti-thyroid peroxidase, anti-thyroglobulin and anti-gastric parietal cells antibodies in Czech population. Physiol Res 57 (Suppl 1): S135-S141, 2008.

STINCA S, ANDERSSON M, WEIBEL S, HERTER-AEBERLI I, FINGERHUT R, GOWACHIRAPANT S, HESS SY, JAISWAL N, JUKIC T, KUSIC Z, MABAPA NS, NEPAL AK, SAN LUIS TO, ZHEN JQ, ZIMMERMANN MB: Dried blood spot thyroglobulin as a biomarker of iodine status in pregnant women. J Clin Endocrinol Metab 102: 23-32, 2017. https://doi.org/10.1210/jc.2016-2829

TENG X, SHAN Z, CHEN Y, LAI Y, YU J, SHAN L, BAI X, LI Y, LI N, LI Z, WANG S, XING Q, XUE H, ZHU L, HOU X, FAN C, TENG W: More than adequate iodine intake may increase subclinical hypothyroidism and autoimmune thyroiditis: a cross-sectional study based on two Chinese communities with different iodine intake levels. Eur J Endocrinol 164: 943-950, 2011. https://doi.org/10.1530/EJE-10-1041

THOMSON CD, WOODRUFFE S, COLLS AJ, JOSEPH J, DOYLE TC: Urinary iodine and thyroid status of New Zealand residents. Eur J Clin Nutr 55: 387-392, 2001. https://doi.org/10.1038/sj.ejcn.1601170

VAN DEN BRIEL T, WEST CE, HAUTVAST JG, VULSMA T, DE VIJLDER JJ, ATEGBO EA: Serum thyroglobulin and urinary iodine concentration are the most appropriate indicators of iodine status and thyroid function under conditions of increasing iodine supply in schoolchildren in Benin. J Nutr 131: 2701-2706, 2001. https://doi.org/10.1093/jn/131.10.2701

VENKATESH SG, DESHPANDE V: A comparative review of the structure and biosynthesis of thyroglobulin. Comp Biochem Physiol C Pharmacol Toxicol Endocrinol 122: 13-20, 1999. https://doi.org/10.1016/S0742$\underline{8413(98) 10075-0}$

WHO 2001: Assessment of iodine deficiency disorders and monitoring their elimination: a guide for programme managers. World Health Organization, UNICEF, ICCIDD, WHO/NHD/01.1, Geneva, 2001.

WHO 2004: Iodine status worldwide. In: World Health Organization Global Database on Iodine Deficiency. B DE BENOIST, BM ANDERSSON, I EGLI, B TAKKOUCHE, H ALLEN (eds), WHO Department of Nutrition for Health and Development, Geneva, 2004. 
WHO 2007: Assessment of iodine deficiency disorders and monitoring their elimination: a guide for programme managers (3rd ed.). WHO, UNICEF, ICCIDD, Geneva, 2007.

WHO 2013: State of the science of endocrine disrupting chemicals 2012. A BERGMAN, S JOBLING, KA KIDD, RT ZOELLER (eds), United Nations Environment Programme and the World Health Organization, WHO Press, Geneva, 2013.

WHO 2016: International statistical classification of diseases and related health problems, ICD-10 (5th ed.). World Health Organization, Geneva, 2016.

ZAMRAZIL V, BILEK R, CEROVSKA J, DELANGE F: The elimination of iodine deficiency in the Czech Republic: the steps toward success. Thyroid 14: 49-56, 2004. https://doi.org/10.1089/105072504322783849

ZAMRAZIL V, BILEK R, CEROVSKA J, DVORAKOVA M, HOSKOVCOVA P, STERZL I: Evaluation of iodine prophylaxis in Czech Republic: changes of ioduria, thyroid status and autoimmunity. In: Comprehensive Handbook on Iodine: Nutritional, Biochemical, Pathological and Therapeutic Aspects. VR PREEDY, GN BURROW, R WATSON (eds), Academic Press, Oxford, 2009, pp 835-845. https://doi.org/10.1016/B9780-12-374135-6.00086-8

ZAMRAZIL V, BÍLEK R, HORÁKOVÁ L, GOŠ R: Changes in the occurrence of thyroid disease in the Czech Republic according to VZP registry in 2012-2015. (In Czech) Prakt Lek 97: 184-185, 2017.

ZIMMERMANN MB: Iodine deficiency. Endocr Rev 30: 376-408, 2009. https://doi.org/10.1210/er.2009-0011

ZIMMERMANN MB: The importance of adequate iodine during pregnancy and infancy. World Rev Nutr Diet 115 : 118-124, 2016. https://doi.org/10.1159/000442078

ZIMMERMANN MB, DE BENOIST B, CORIGLIANO S, JOOSTE PL, MOLINARI L, MOOSA K, PRETELL EA, AL-DALLAL ZS, WEI Y, ZU-PEI C, TORRESANI T: Assessment of iodine status using dried blood spot thyroglobulin: development of reference material and establishment of an international reference range in iodine-sufficient children. J Clin Endocrinol Metab 91: 4881-4887, 2006. https://doi.org/10.1210/jc.2006-1370

ZIMMERMANN MB, AEBERLI I, ANDERSSON M, ASSEY V, YORG JA, JOOSTE P, JUKIC T, KARTONO D, KUSIC Z, PRETELL E, SAN LUIS TO JR, UNTORO J, TIMMER A: Thyroglobulin is a sensitive measure of both deficient and excess iodine intakes in children and indicates no adverse effects on thyroid function in the UIC range of 100-299 $\mu \mathrm{g} / \mathrm{L}$ : a UNICEF/ICCIDD study group report. J Clin Endocrinol Metab 98: 1271-1280, 2013. https://doi.org/10.1210/jc.2012-3952 